\title{
Clinical, behavioral and antinociceptive effects of crotalphine in horses
}

\author{
Efeitos clínico, comportamental e antinociceptivo da crotalfina em equinos
}

\author{
Erica Cristina Bueno do Prado Guirro' João Henrique Perotta ${ }^{\text {II }}$ Márcio de Paula \\ Yara Cury ${ }^{\mathrm{IV}}$ Carlos Augusto Araújo Valadãov
}

\section{ABSTRACT}

Crotalphine is a novel analgesic peptide that acts on kappa opioid and delta receptors, causing powerful analgesia in rats submitted to inflammatory, neuropathic or oncologic models of pain. This study evaluated clinical, behavioral and antinociceptive effects caused by crotalphine in horses, employing 18 Arabian horses and it was divided in three phases. In Phase I, "clinical and behavioral effects", crotalphine did not change the latency to urinate and defecate; did not modify the values of cardiac or respiratory rates, intestinal motility and rectal temperature; and did not cause significant ataxia, head, eye and lip ptosis. In Phase II, "antinociceptive effect on intact skin at scapular or ischial region", crotalphine did not cause significant analgesia. In Phase III, "antinociceptive effect on incised skin at scapular or ischial region", crotalphine promoted effective antinociceptive effects for six hours and inhibited hyperalgesia state for three days in the ischial region of horses submitted to incisional model of inflammatory pain, but crotalphine did not evoke relevant analgesic effect on the scapular region. Concluding, intravenous injection of a single dose of crotalphine $\left(3.8 n \mathrm{gkg}^{-1}\right)$ did not cause important clinical or behavioral changes and promotes antinociceptive effect on incised ischial region for seven days in horses. Moreover, crotalphine did not evoke relevant anti nociceptive effect on the scapular region or in intact skin of horses.

Key words: crotalphine, horses, kappa, nociception, opioids.

\section{RESUMO}

A crotalfina é um novo peptídeo analgésico que atua em receptores opioides kappa e delta, causando analgesia potente em ratos submetidos a modelos de dorinflamatória, neuropática e oncológica. Este estudo avaliou os efeitos clínicos, comportamental e antinociceptivo da crotalfina em equinos, empregou 18 cavalos da raça Puro Sangue Árabe e foi dividido em três fases. Na Fase I, "efeitos clínicos e comportamentais", a crotalfina não alterou a latência para urinar e defecar; não interferiu nos valores de frequência cardiaca ou respiratória, motilidade intestinal etemperatura retal; e não causou ataxia, ptose labial, palpebral ou de cabeça significativas. Na Fase II, "efeito antinociceptivo na pele integra da região escapular ou isquiática”, a crotalfina não gerou analgesia significativa. Na Fase III, "efeito antinociceptivo na pele incisada da região escapular ou isquiática”, a crotalfina promoveu efeito antinociceptivo efetivo por seis horas e inibição da hiperalgesia por três dias na região isquiática de equinos submetidos ao modelo incisional de dor inflamatória, mas não houve analgesia relevante na região escapular. Conclui-se que uma única injeção de crotalfina $\left(3,8 n \mathrm{~kg}^{-1}\right)$ não causa alterações clínicas ou comportamentais importantes e promove efeito antinociceptivo na região isquiática incisionada durante sete dias em equinos. Além disso, a crotalfina não evoca efeito antinociceptivo relevante na região escapular e nem na pele intacta de cavalos.

Palavras-chave: cavalos, crotalfina, kappa, nocicepção, opioides.

\section{INTRODUCTION}

Agonist opioids bind to mu, kappa and delta receptors promoting analgesia by reduction of neuronal transmission (SCHULTZ \& GROSS, 2001). Studies on the effects of kappa agonists have been done and it has been noticed that U50-488H, considered as archetype of group, promotes analgesia without altering the locomotor activity of horses (KAMERLING et al., 1988).

\footnotetext{
'Departamento de Ciências Veterinárias, Universidade Federal do Paraná (UFPR), Setor Palotina, Rua Pioneiro, 2153, Jd. Dallas, 85950-000, Palotina, PR, Brasil. E-mail: ericaguirro@ufpr.br. Corresponding author.

IIDepartamento de Medicina Veterinária, Universidade Federal do Paraná (UFPR), Setor Agrárias, Curitiba, PR, Brasil.

"IIConsórcio da Indústria Farmacêutica (COINFAR), São Paulo, SP, Brasil.

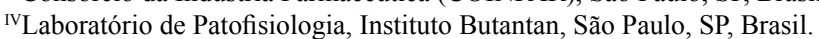

vDepartamento de Clínica e Cirurgia Veterinária, Universidade Estadual Paulista (UNESP), Jaboticabal, SP, Brasil. Received 04.02.14 Approved 08.31.15 Returned by the author 11.23.15 CR-2014-0498.R4
} 
In the 1950s, Vital Brazil observed absence of inflammation and local analgesia after Crotalus durissus terrificus bites (SOUSA E SILVA et al., 1996). In rats, crotalic venom causes prolonged analgesia in models of inflammatory (BRIGATTE et al., 2001), neuropathic (GUTIERREZ et al., 2008) or oncologic pain (BRIGATTE et al., 2013). The analgesic peptide in the crotalic venom was identified, characterized, synthesized and is currently called crotalphine (GIORGI et al., 1993). It acts on kappa receptors present in supraspinal centers of the central nervous system (PICOLO et al., 1998; BRIGATTE et al., 2001). Peripherally, crotalphine binds to kappa and delta receptors and also involves the NOGMPc L-arginine pathway and the ATP-sensitive K+ channels (PICOLO et al., 2000; PICOLO et al., 2003; PICOLO \& CURY, 2004).

Pre-clinical assays with crotalphine verified powerful and persistent analgesia in rodents without severe side effects (PICOLO et al., 2000; BRIGATTE et al., 2001; PICOLO \& CURY, 2004; NUNES et al., 2007). Besides pre-clinical studies, there is only one study that had already evaluated antinociception promoted by crotalphine and no analgesia was observed in horses submitted to thermal stimulation on intact skin (GUIRRO et al., 2013).

The aim of this study was to evaluate the clinical, behavioral and antinociceptive effects promoted by a single injection of crotalphine in horses.

\section{MATERIAL AND METHODS}

Nine castrated male and nine non-pregnant female Arabian horses, between four and six years old and $377 \pm 27 \mathrm{~kg}$ were selected after physical exam, hemogram and total protein measurement. Each group was composed of four males and four females. Some animals were used more than once, in different groups, respecting intervals of 14 days between repetitions.

Crotalphine is still in test and is not available for commercial sale so far. The dose of crotalphine (3.8ng $\mathrm{kg}^{-1}$ ) employed in this study was calculated by allometric extrapolation from the dose used in rats and was previously tested in a pilot study with six horses.

Phase I - Clinical and behavioural effects

The horses were positioned in a horse stock at $8 \mathrm{am}$ and received a jugular catheter. After 30min resting, at basal time $\left(\mathrm{T}_{\mathrm{B}}\right)$, heart rate $(\mathrm{bpm})$; respiratory rate $(\mathrm{mpm})$; rectal temperature $\left({ }^{\circ} \mathrm{C}\right)$; intestinal motility, in scores ( 0 - no motility; 1 -incomplete movement; 2 -hypomotility; 3 -normal motility; 4 -hypermotility); head ptosis, mensuring the height of the head before and after administration of the drug and, to avoid discrepancies among horses, the percentage of the change was calculated; palpebral and lip ptosis (0 absence; 1 - presence); and ataxia, in scores, adapted from BRYANT et al. (1991) (0 - stability; 1 - reduction of stability with some lateral movement; 2 - more intense lateral movement, trend to inclination; 3 -pelvic support in the stock, members crossed, sudden and frequent flexion of carpal joints) were evaluated.

At T0, drugs were injected with regards to group: $\mathrm{GC}(5 \mathrm{~mL} \mathrm{NaCl} 0.9 \%)$, GCRO $\left(3.8 \mathrm{ngkg}^{-}\right.$ ${ }^{1}$ crotalphine) or GK $\left(160 \mu \mathrm{kg}^{-1} \mathrm{U} 50-488 \mathrm{H}\right)$. Final volume was adjusted to $5 \mathrm{~mL}$ and injection was given within 30 seconds. Immediately, parameters were recorded and other evaluations were carried out in T30 (min), T60, T90, T2h (hours), T3h, T6h, T12h, T24h, T2d (days), T3d, T5d and T7d. Moreover, latency and percentage of animals that had urinated and defecated until T3h were evaluated.

Phase II - Antinociceptive effect on intact skinin the scapular or ischial regions

A vertical line $(5 \mathrm{~cm})$ with rectangles at 1,3 and $5 \mathrm{~cm}$ was drawn in the scapular and contra-lateral ischial regions (top of the line was the projection of the ischial tuberosity beneath the skin). The horses received a jugular catheter, had their tails bandaged and after $30 \mathrm{~min}$ resting $\left(T_{B}\right)$, the nociceptive threshold to mechanical stimuli was evaluated in the scapular (NTMSsca) and ischial (NTMSisc) regions using von Frey filaments to verify the mean of cutaneous sensitivity at 1,3 and $5 \mathrm{~cm}$ around the vertical central line. NTMS was determined by the major filament unable to provoke aversive response (average among values obtained at 1, 3 and $5 \mathrm{~cm})$. Twenty minutes later (T0), drugs were injected: GC (5mL NaCl $0.9 \%$ ) or GCRO (3.8ngkg-1 ${ }^{-1}$ crotalphine). Immediately, NTMSsca and NTMSisc were evaluated and new evaluations were carried out at T3h, T6h, T12h, T24h, T2d, T3d, T5d andT7d.

Phase III - Antinociceptive effect on incised skin in the scapular or ischial regions

A vertical line $(5 \mathrm{~cm})$ with rectangles at 1,3 and $5 \mathrm{~cm}$ was drawn in the scapular and contralateral ischial regions. The horses received a jugular catheter, had their tails bandaged and, in sequence, lidocaine $2 \%(5 \mathrm{~mL}, \mathrm{SC})$ was administered along the vertical central line of the scapular and contra-lateral ischial region. Then, the skin was incised $(5 \mathrm{~cm})$ on the line and immediately sutured.

After 30min resting (TB), NTMSsca and NTMSisc were evaluated as in Phase II. Twenty minutes later (T0), drugs were injected: GCRO 
(3.8ngkg ${ }^{-1}$ crotalphine), GM $\left(0.1 \mathrm{mgkg}^{-1}\right.$ morphine), GK $\left(160 \mu \mathrm{kg}^{-1} \mathrm{U} 50-488 \mathrm{H}\right)$ or GP $\left(4.4 \mathrm{mgkg}^{-1}\right.$ phenylbutazone), and NTMSsca and NTMSisc were evaluated again and repeatedly at $\mathrm{T} 3 \mathrm{~h}, \mathrm{~T} 6 \mathrm{~h}$, T12h, T24h, T2d, T3d, T5d, and T7d. In this phase, there was not a GC group to respect animal welfare and the 3 Rs principle.

Statistical analysis

Heart and respiratory rate, rectal temperature, latency to urinate and defecate were analyzed by ANOVA followed by Tukey $(\mathrm{P}<0.05)$. Non-parametric variables were analyzed by Kruskal-Wallis $(\mathrm{P}<0,05)$. Regarding NTMS, Kruskal-Wallis was used to compare values along time and among groups; and Mann Whitney, to verify differences between regions and between intact and incised skin $(\mathrm{P} \leq 0.05)$.

\section{RESULTS AND DISCUSSION}

No animal of GC urinated until T3h, while $17 \%$ of GCRO and $50 \%$ of GK did. Latency in GC was greater than $180 \mathrm{~min}$; in GCRO and GK it was $168 \pm 13 \mathrm{~min}$ and $126 \pm 24 \mathrm{~min}$, respectively. Crotalphine and $\mathrm{U} 50-488 \mathrm{H}$ must have similar responses because both are kappa agonists and no changes in diuresis parameters were reported after use of U50-488H in horses (KAMERLING et al., 1989).
Until three hours, $67 \%$ of the horses of GC, $83 \%$ of GCRO and $50 \%$ of GK defecated and latency was $70 \pm 35 \mathrm{~min}, 82 \pm 25 \mathrm{~min}$ and $34 \pm 29 \mathrm{~min}$, respectively. This similarity among groups proves that kappa opioids do not interfere in intestinal motility (BUENO \& FIORAMONTI, 1988; ROGER et al., 1994). Intestinal motility did not significantly change because kappa agonists do not change gastrointestinal motility (SMITH \& CHANG. 1993). ROGER et al. (1994) had already no changes in cecocolic motility after injection of U50- $488 \mathrm{H}$ in ponies, suggesting that kappa agonist can be better than mu opioids to relieve visceral pain in equine colic without interferences in motility (KAMERLING et al., 1989; DUCHARME, 2003). Crotalphine is a kappa agonist and thus the same effects caused by U50-488H in horses are expected. Perhaps, crotalphine may be an alternative to reducing pain in horses with intestinal discomfort, but this hypothesis is yet to be confirmed in future studies.

Heart rate, respiratory rate and rectal temperature (Table 1) did not change significantly and values of GCRO and GK were similar. Subtle changes were verified in rectal temperature, but values remained within physiological range. Importantly, environmental temperature was not controlled and varied from $21^{\circ} \mathrm{C}$ to $31^{\circ} \mathrm{C}$ according to official meteorological sources. Crotalphine and U50-488H

Table 1 - Standard heart rate $(\mathrm{HH})$, respiratory rate $(\mathrm{RR})$ and rectal temperature $(\mathrm{RT})$ (mean \pm SE) observed in Arabian horses after intravenous injection of $5 \mathrm{~mL} \mathrm{NaCl} 0.9 \%$ (GC), $3.8 \mathrm{ngkg}^{-1}$ crotalphine (GCRO) or $160 \mu \mathrm{gkg}^{-1} \mathrm{U}_{50-488 \mathrm{H}}(\mathrm{GK})$.

\begin{tabular}{|c|c|c|c|c|c|c|c|c|c|}
\hline & HR (bpm) & $\mathrm{RR}$ (mpm) & $\mathrm{RT}\left({ }^{\circ} \mathrm{C}\right)$ & HR (bpm) & $\mathrm{RR}$ (mpm) & $\mathrm{RT}\left({ }^{\circ} \mathrm{C}\right)$ & HR (bpm) & $\mathrm{RR}$ (mpm) & $\mathrm{RT}\left({ }^{\circ} \mathrm{C}\right)$ \\
\hline TB & $40.7 \pm 3.0$ & $26.7 \pm 3.2$ & $37.5 \pm 0.1$ & $36.7 \pm 1.8$ & $22.0 \pm 2.8$ & $37.3 \pm 0.1$ & $41.2 \pm 3.2$ & $22.7 \pm 3.0$ & $37.3 \pm 0.1$ \\
\hline T0 & $41.0 \pm 3.0$ & $26.7 \pm 3.0$ & $37.8 \pm 0.1$ & $35.0 \pm 1.1$ & $22.7 \pm 2.8$ & $37.4 \pm 0.1$ & $38.7 \pm 1.8$ & $26.7 \pm 5.7$ & $37.6 \pm 0.2$ \\
\hline Т30 & $42.0 \pm 2.5$ & $27.0 \pm 2.7$ & $37.7 \pm 0.1$ & $35.0 \pm 0.9$ & $25.3 \pm 2.3$ & $37.6 \pm 0.1$ & $39.7 \pm 1.7$ & $28.0 \pm 5.3$ & $37.7 \pm 0.1$ \\
\hline T60 & $41.0 \pm 3.3$ & $28.7 \pm 2.3$ & $37.8 \pm 0.1$ & $35.7 \pm 1.0$ & $27.0 \pm 2.9$ & $37.5 \pm 0.1$ & $42.7 \pm 2.3$ & $29.7 \pm 4.7$ & $37.9 \pm 0.1$ \\
\hline Т90 & $37.7 \pm 2.2$ & $25.3 \pm 3.2$ & $37.8 \pm 0.1$ & $35.0 \pm 1.3$ & $27.0 \pm 2.7$ & $37.5 \pm 0.1$ & $41.7 \pm 2.8$ & $25.7 \pm 3.6$ & $37.9 \pm 0.2$ \\
\hline $\mathrm{T} 2 \mathrm{~h}$ & $37.3 \pm 2.4$ & $26.8 \pm 3.0$ & $37.9 \pm 0.1$ & $34.7 \pm 1.2$ & $25.3 \pm 3.3$ & $37.7 \pm 0.1$ & $39.3 \pm 1.3$ & $28.7 \pm 3.4$ & $37.8 \pm 0.2$ \\
\hline $\mathrm{T} 3 \mathrm{~h}$ & $44.3 \pm 4.1$ & $28.7 \pm 4.6$ & $38.2 \pm 0.1 \mathrm{a}$ & $40.7 \pm 1.1$ & $28.3 \pm 4.8$ & $37.9 \pm 0.1$ & $44.0 \pm 3.0$ & $29.7 \pm 6.7$ & $37.8 \pm 0.2$ \\
\hline T6h & $47.3 \pm 5.1$ & $27.0 \pm 1.8$ & $37.8 \pm 0.1$ & $39.7 \pm 1.2$ & $26.7 \pm 2.5$ & $38.1 \pm 0.1 \mathrm{a}$ & $43.0 \pm 3.2$ & $28.7 \pm 6.1$ & $38.2 \pm 0.1 \mathrm{a}$ \\
\hline $\mathrm{T} 12 \mathrm{~h}$ & $45.3 \pm 5.0$ & $23.3 \pm 2.4$ & $38.1 \pm 0.1$ & $39.7 \pm 2.3$ & $22.0 \pm 2.3$ & $37.7 \pm 0.1$ & $42.3 \pm 2.2$ & $19.0 \pm 3.0$ & $37.8 \pm 0.1$ \\
\hline $\mathrm{T} 24 \mathrm{~h}$ & $46.0 \pm 4.2$ & $28.4 \pm 5.3$ & $37.7 \pm 0.2$ & $38.3 \pm 2.2$ & $27.3 \pm 2.6$ & $37.6 \pm 0.1$ & $39.3 \pm 3.1$ & $22.8 \pm 3.4$ & $37.2 \pm 0.2$ \\
\hline $\mathrm{T} 3 \mathrm{~d}$ & $40.7 \pm 2.2$ & $26.3 \pm 4.2$ & $37.7 \pm 0.2$ & $38.3 \pm 1.4$ & $26.0 \pm 3.4$ & $37.2 \pm 0.2$ & $35.0 \pm 2.1$ & $22.7 \pm 1.4$ & $37.3 \pm 0.1$ \\
\hline $\mathrm{T} 5 \mathrm{~d}$ & $38.0 \pm 3.8$ & $26.7 \pm 3.4$ & $37.8 \pm 0.1$ & $32.0 \pm 1.9$ & $25.5 \pm 2.0$ & $37.3 \pm 0.1$ & $34.7 \pm 1.2$ & $20.0 \pm 3.4$ & $37.5 \pm 0.1$ \\
\hline $\mathrm{T} 7 \mathrm{~d}$ & $37.2 \pm 3.6$ & $25.2 \pm 5.0$ & $37.5 \pm 0.1$ & $34.3 \pm 1.4$ & $20.7 \pm 2.4$ & $37.2 \pm 0.1$ & $36.0 \pm 1.6$ & $19.0 \pm 4.2$ & $37.1 \pm 0.1$ \\
\hline
\end{tabular}

a - significant difference of $\mathrm{T}_{\mathrm{B}}(\mathrm{P} \leq 0.05)$.

TB: basal time; T0: immediately after intravenous injection of drugs; T30: 30 minutes after intravenous injection of drugs; T60: 60 minutes after intravenous injection of drugs; T90 minutes after intravenous injection of drugs; T2h: two hours after intravenous injection of drugs; T3h: three hours after intravenous injection of drugs; T6h: six hours after intravenous injection of drugs; T12h: 12 hours after intravenous injection of drugs; T24h: 24 hours after intravenous injection of drugs; T3d: three days after intravenous injection of drugs; T5d: five days after intravenous injection of drugs; T7d: seven days after intravenous injection of drugs. 
are kappa opiodsagonists and KAMERLING et al. (1988) had already described only minimal clinical changes after the use of this class of drugs.

Head, palpebral and lip ptosis and ataxia were not observed in any group. KAMERLING et al. (1988) and KAMERLING et al. (1989) already reported absence of behavioral changes after administration of kappa agonists.

Regarding the antinociceptive effect caused by crotalphine (Table 2), in a general way, it was possible to observe that crotalphine was more efficient than other drugs, mainly on incised skin of the ischial region. In any given moment, NTNSsci was lesser than the value observed at $T_{B}$ in GCRO and, until T6h, the NTNSsci was greater than $T_{B}$. Comparing NTMSsca and NTMSisc from intact and incised skin, values in the ischial region were always significantly higher. Effects caused by crotalphine were more relevant at ischial region and comparing intact versus injured skin it could be observed that in the intact skin the crotalphine does not increase pain threshold.
Nociceptive stimuli are conducted by different sensitive fibers to the dorsal horn of the spinal medulla and opioids modulate the nociceptive response and cause antinociceptive effect (TRUONG et al., 2003). As observed, crotalphine promoted more analgesia on inflamed tissue and this findingis supported by previous studies which revealed that expression and distribution of receptors in damaged tissue change the potency of opioids (VAN LOON et al., 2013); there is also activation of peripheral opioid receptors depending on the stage of the inflammatory reaction and opioids do not always act the same way on intact tissue because they induce release of IL-10, which has anti-inflammatory effect (JOHNSTON et al., 2004; IWASZKIEWICZ, 2013) and increase plasmatic level of glucocorticoids by stimulation of the hypothalamicpituitary-adrenal axis (CHISARI et al., 1998). Besides, crotalphine was more efficient in the ischial region because mu receptors are distributed along the spinal medulla in horses, while kappa and delta receptors are restricted to the lumbosacral and cervical segments, respectively (VALADÃO et al., 2002).

Table 2 - Nociceptive threshold of mechanical stimuli in the scapular (NTMSsca) and ischial (NTMSisc) regions observed in Arabian horses

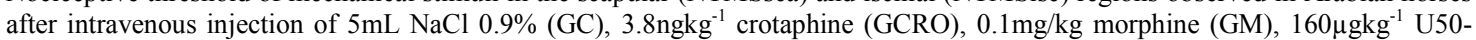
$488 \mathrm{H}(\mathrm{GK})$ or $4.4 \mathrm{mgkg}^{-1}$ phenylbutazone $(\mathrm{GP})$, in grams (mean $\left.\pm \mathrm{SE}\right)$.

\begin{tabular}{|c|c|c|c|c|c|c|c|c|c|c|c|c|}
\hline & & & $\mathrm{T}_{\mathrm{B}}$ & $\mathrm{T}_{0}$ & $\mathrm{~T}_{3 \mathrm{~h}}$ & $\mathrm{~T}_{6 \mathrm{~h}}$ & $\mathrm{~T}_{12 \mathrm{~h}}$ & $\mathrm{~T}_{24 \mathrm{~h}}$ & $\mathrm{~T}_{2 \mathrm{~d}}$ & $\mathrm{~T}_{3 \mathrm{~d}}$ & $\mathrm{~T}_{5 \mathrm{~d}}$ & $\mathrm{~T}_{7 \mathrm{~d}}$ \\
\hline \multirow{5}{*}{$\begin{array}{l}\text { INTACT } \\
\text { SKIN }\end{array}$} & \multirow{2}{*}{ NTMSsca } & $\mathrm{GC}$ & $156 \pm 13$ & $261 \pm 27 \#$ & $17 \pm 12^{*} \#$ & $104 \pm 25^{*} \#$ & $76 \pm 23^{*} \#$ & $85 \pm 24^{*}$ & $172 \pm 30 \#$ & $223 \pm 31^{*}$ & $193 \pm 45^{*}$ & $224 \pm 31^{*}$ \\
\hline & & GCRO & $156 \pm 13$ & $80 \pm 23^{*}$ & $5 \pm 5^{*}$ & $5 \pm 5^{*}$ & $39 \pm 17^{*}$ & $21 \pm 11^{*}$ & $86 \pm 23^{*}$ & $81 \pm 23^{*}$ & $78 \pm 22^{*}$ & $120 \pm 27^{*}$ \\
\hline & \multirow{3}{*}{ NTMSisc } & & & & & & & & & & & \\
\hline & & GC & $342 \pm 11 \mathrm{a}$ & $390 \pm 17 \# \mathrm{a}$ & $204 \pm 29^{*} \mathrm{\# a}$ & $213 \pm 30^{*} \# \mathrm{a}$ & $167 \pm 28^{*} \# \mathrm{a}$ & $\mathrm{a} 218 \pm 30^{*} \mathrm{\# a}$ & $a 300 \pm 29 a$ & $315 \pm 28 \# \mathrm{a}$ & $365 \pm 24 \# \mathrm{a}$ & $372 \pm 23 a$ \\
\hline & & GCRO & $342 \pm 11 \mathrm{a}$ & $438 \pm 8 \mathrm{a}$ & $316 \pm 28 \mathrm{a}$ & $361 \pm 24 a$ & $378 \pm 20 \mathrm{a}$ & $377 \pm 22 \mathrm{a}$ & $373 \pm 23 a$ & $444 \pm 3^{*} \mathrm{a}$ & $447 \pm 0^{*} \mathrm{a}$ & $447 \pm 0^{*} \mathrm{a}$ \\
\hline \multirow{8}{*}{$\begin{array}{l}\text { INCISED } \\
\text { SKIN }\end{array}$} & \multirow{4}{*}{ NTMSsca } & GCRO & $156 \pm 13$ & $61 \pm 17^{*} \&$ & $155 \pm 24 \&$ & $56 \pm 16^{*} \&$ & $56 \pm 17^{*}$ & $38 \pm 15^{*} \&$ & $61 \pm 18^{*} \&$ & $72 \pm 19^{*} \&$ & \multicolumn{2}{|c|}{$100 \pm 21^{*} \& 13 \pm 9^{*} \&$} \\
\hline & & GM & $156 \pm 13$ & $197 \pm 25 \#$ & $121 \pm 20$ & $41 \pm 13^{*}$ & $59 \pm 16^{*}$ & $64 \pm 17^{*} \#$ & $43 \pm 15^{*}$ & $69 \pm 17^{*}$ & $15 \pm 9^{*} \#$ & $7 \pm 61^{*}$ \\
\hline & & GK & $156 \pm 13$ & $275 \pm 26^{*} \#$ & $158 \pm 22$ & $202 \pm 28 \#$ & $22 \pm 8^{*} \#$ & $30 \pm 14^{*}$ & $0 \pm 0^{*} \#$ & $42 \pm 16^{*}$ & $33 \pm 14^{*} \#$ & $67 \pm 21^{*} \#$ \\
\hline & & GP & $156 \pm 13$ & $28 \pm 11^{*}$ & $1 \pm 0^{*} \#$ & $2 \pm 1^{*} \#$ & $0 \pm 0^{*} \#$ & $54 \pm 15^{*}$ & $0 \pm 0^{*} \#$ & $48 \pm 14^{*} \#$ & $50 \pm 15^{*} \#$ & $12 \pm 6^{*} \#$ \\
\hline & \multirow{4}{*}{ NTMSisc } & GCRO & $342 \pm 11 a$ & $353 \pm 1 \& a$ & $440 \pm 5 \&^{*} \mathrm{a}$ & $458 \pm 18^{*} \& a$ & $395 \pm 15 \&$ & $\mathrm{a} 387 \pm 17 \& \mathrm{a}$ & $394 \pm 16 \&$ & $a 388 \pm 16 \& a$ & $374 \pm 16 a$ & $388 \pm 14 a$ \\
\hline & & GM & $342 \pm 11 \mathrm{a}$ & $349 \pm 18 \mathrm{a}$ & $284 \pm 23^{*} \# \mathrm{a}$ & $246 \pm 23^{*} \# \mathrm{a}$ & $267 \pm 22^{*} \# \mathrm{a}$ & $\mathrm{a} 330 \pm 23 \mathrm{a}$ & $321 \pm 22 \mathrm{a}$ & $336 \pm 24 \# \mathrm{a}$ & $353 \pm 20 \mathrm{a}$ & $328 \pm 20 a$ \\
\hline & & GK & $342 \pm 11 \mathrm{a}$ & $336 \pm 23 a$ & $297 \pm 24 \# \mathrm{a}$ & $304 \pm 25 \# a$ & $314 \pm 28 \# \mathrm{a}$ & $336 \pm 24 a$ & $343 \pm 27 \mathrm{a}$ & $351 \pm 24 a$ & $397 \pm 16 a$ & $356 \pm 23 a$ \\
\hline & & GP & $342 \pm 11 \mathrm{a}$ & $193 \pm 24^{*} \# \mathrm{a}$ & $176 \pm 23^{*} \#$ & $187 \pm 22^{*} \mathrm{Aa}$ & a $198 \pm 23^{*} \#$ a & a $159 \pm 23^{*}$ a & $174 \pm 22^{*} \# \mathrm{a}$ & $\mathrm{a} 214 \pm 20^{*} \mathrm{\# a}$ & $1290 \pm 22^{*} \mathrm{\# a}$ & $\mathrm{a} 332 \pm 18^{*} \# \mathrm{a}$ \\
\hline
\end{tabular}

\footnotetext{
${ }^{*}$ significant difference from $\mathrm{TB}(\mathrm{P} \leq 0.05)$.

\# significant difference from GCRO $(\mathrm{P} \leq 0.05)$.

$\&$ - significant difference from intact skin $(\mathrm{P} \leq 0.05)$

a - significant difference from NTMSsca $(\mathrm{P} \leq 0.05)$

TB: basal time; T0: immediately after intravenous injection of drugs; T30: 30 minutes after intravenous injection of drugs; T60: 60 minutes after intravenous injection of drugs; T90 minutes after intravenous injection of drugs; T2h: two hours after intravenous injection of drugs; T3h: three hours after intravenous injection of drugs; T6h: six hours after intravenous injection of drugs; T12h: 12 hours after intravenous injection of drugs; T24h: 24 hours after intravenous injection of drugs; T3d: three days after intravenous injection of drugs; T5d: five days after intravenous injection of drugs; T7d: seven days after intravenous injection of drugs.
} 
Crotalphine acts similarly to crotalic venom, hence, analgesic effect produced by them be similar. In this study, long-term analgesia was observed and, in the model of hyperalgesia induced by carrageenan in rats, a single injection of crotalic venom caused potent analgesia after stimulation of the pelvic limb (PICOLO et al., 1998; PICOLO \& CURY, 2004) and anti-inflammatory effects for seven days. This suggests that crotalic venom has prolonged anti-inflammatory activity and that the analgesic effect is better when this drug is administered at the beginning of the inflammation (NUNES et al., 2007) as done in the present study.

Antinociceptive effect of crotalphine had two phases best observed in the incised ischial region. In the first phase (T0 to T6h), NTMSisc was higher than what was observed in intact skin; in the second (from T6h to T3d), NTMSisc was similar to $\mathrm{T}_{\mathrm{B}}$. Long-term analgesia caused by crotalphine corroborates PICOLO et al. (1998), who reported long analgesia after crotalic venom injection in rodents, reflecting action on the hypothalamic-pituitary-adrenalaxis (CHISARI et al., 1998) and reduction of hyperalgesia in the inflamed area through inhibition of central sensitization (STUBHAUG et al., 1997).

\section{CONCLUSION}

Intravenous injection of a single dose of crotalphine $\left(3.8 \mathrm{ngkg}^{-1}\right)$ does not cause important clinical or behavioral changes and promotes antinociceptive effect on the incised ischial region for seven days in horses. Moreover, crotalphine does not evoke relevant antinociceptive effect on the scapular region or on theintact skin of horses.

\section{ACKNOWLEDGEMENTS}

Thanks to Mr. Wiliiam Marandola, from Consórcio da Indústria Farmacêutica (COINFAR), by crotalphine donation. To Fundação de Amparo à Pesquisa do Estado de São Paulo (FAPESP) (process n. 05/04480-0) and Conselho Nacional de Desenvolvimento Científico e Tecnológico $(\mathrm{CNPq})$ (process $\mathrm{n}$. 140038/2006-0) by financial support.

\section{BIOETHICS AND BIOSSECURITY COMMITTEE APPROVAL}

This study was approved by the Bioethics Committee of FCAV/UNESP, Jaboticabal, (protocol n. 09974-05).

\section{REFERENCES}

BRIGATTE, P. et al. Peripheral kappa and delta opioid receptors are involved in the antinociceptive effect of crotalphine in a rat model of cancer pain. Pharmacology, Biochemistry and Behavior, v.109. p.1-7, 2013. Available from: <http://www.ncbi. nlm.nih.gov/pubmed/23628488>. Accessed: Feb. 17, 2014. doi: 10.1016/j.pbb.2013.04.012.

BRIGATTE, P. et al. Tolerance to the antinociceptive effect of Crotalus durissus terrificus snake venom in mice is mediate by pharmacodynamic mechanisms. Toxicon, v.39, p.13991410, 2001. Available from: <http://www.ncbi.nlm.nih.gov/ pubmed/11384730>. Accessed: Feb. 08, 2014.

BRYANT, C.E. et al. Comparison of the sedative effects of medetomidine and xylazine in horses. Veterinary Record, v.129, p.421-423, 1991. Available from: <http://www.ncbi.nlm.nih.gov/ pubmed/1776221>. Accessed: Feb. 27, 2014.

BUENO.L.; FIORAMONTI. J. Action of opiates on gastrointestinal function. Baillière's Clinical Gastroenterology, v.2, p.123-139, 1988. Available from: <http://www.ncbi.nlm.nih. gov/pubmed/2838107>. Accessed: Mar. 03, 2014.

CHISARI, A. et al. A phospholipase A2-related snake venom (from Crotalus durissus terrificus) stimulates neuroendocrine and immune functions: determination of differentsites of action. Endocrinology, v.139, p.617-625, 1998. Available from: <http://www.ncbi.nlm.nih. gov/pubmed/9449633>. Accessed: Feb. 08, 2014

DUCHARME, N.G. Tratamiento postoperatorio y complicaciones. In: MAIR. T. et al. Manual de gastroenterologia eqüina. Buenos Aires: Inter-Médica. 2003.p.221-282.

GIORGI, R. et al. Analgesic effect evoked by low molecular weight substances extracted from Crotalus durissus terrificus venom. Toxicon, v.31, p.1257-1265, 1993. Available from: <http://www. ncbi.nlm.nih.gov/pubmed/8303720>. Accessed: Mar. 08, 2014.

GUIRRO, E.C.B.P. et al. Ausência de efeito antinociceptivo decorrente da administração intravenosa de crotalfina em comparação com morfina, U50-488H ou fenilbutazona em equinos submetidos à estimulação térmica da pele íntegra. Ciência Rural, v.43, n.4, p.743-749, 2013. Available from: <http://www.scielo.br/ scielo.php?script $=$ sci_arttext\&pid $=$ S010384782013000400028\&1 ng=pt\&nrm=iso $>$. Accessed: Nov. 30, 2014. doi: 10.1590/S010384782013005000021

GUTIERREZ, V.P. et al. Crotalphine induces potent antinociception in neuropathic pain by acting at peripheral opioid receptors. European Journal of Pharmacology, v.594, p.84-92, 2008. Available from: <http://www.ncbi.nlm.nih.gov/pubmed/18703042>. Accessed: Mar. 07, 2014. doi: 10.1016/j.ejphar.2008.07.053.

IWASZKIEWICZ, K.S. et al. Targeting peripheral opioid receptors to promote analgesic and anti-inflammatory actions. Frontiers in Pharmacology, v.4, p.1-7, 2013. Available from: <http://www. ncbi.nlm.nih.gov/pmc/articles/PMC3807052/pdf/fphar-04-00132. pdf $>$. Accessed: Ago.21, 2015. doi: 10.3389/fphar.2013.00132.

JOHNSTON, I.N. et al. A role for proinflammatory cytokines and fractalkine in analgesia, tolerance, and subsequent pain facilitation induced by chronic intrathecal morphine. Journal of Neuroscience, v.24, n.33, p.7353-7365, 2004. Available from: <http://www.jneurosci.org/content/24/33/7353.full.pdf>. Accessed: Ago. 21, 2015. 
KAMERLING, S. et al. Dose related effects of the kappa agonist $\mathrm{U}-50488 \mathrm{H}$ on behavioral, nociception and autonomic response in the horse. Equine Veterinary Journal, v.20, p.114-118, 1988.

KAMERLING, S. et al. Narcotic analgesics.their detection and pain measurement in the horse: a review. Equine Veterinary Journal, v.21.p.4-12, 1989. Available from: <http://www.ncbi. nlm.nih.gov/pubmed/2563969>. Accessed: Mar. 02, 2014.

NUNES, F.P.B. et al. Long-lasting antiinflammatory properties of Crotalus durissus terrificus snake venom in mice. Toxicon, v.49, p.1090-1098, 2007. Available from: <http://www.ncbi.nlm.nih. gov/pubmed/17368497>. Accessed: Mar. 04, 2014.

PICOLO, G. et al. Activation of peripheral ATP-sensitive K+ channels mediates the antinociceptive effect of Crotalus durissus terrificus snake venom. European Journal of Pharmacology, v.469, p.57-64, 2003. Available from: <http://www.ncbi.nlm.nih. gov/pubmed/12782185>. Accessed: Feb. 28, 2014.

PICOLO, G. et al. Delta-opioid receptors and nitric oxide mediate the analgesic effect of Crotalus durissus terrificus snake venom. European Journal of Pharmacology, v.391, p.55-62, 2000. Available from: <http://www.ncbi.nlm.nih.gov/ pubmed/10720635>. Accessed: Mar. 04, 2014.

PICOLO, G. et al. The antinociceptive effect of Crotalus durissu sterrificus snake venom is mainly due to supraspinally integrated response. Toxicon, v.36, p.223-227, 1998. Available from: <http:/ www.ncbi.nlm.nih.gov/pubmed/9604296>. Accessed: Feb. 17, 2014.

PICOLO, G.; CURY, Y. Peripheral neuronal nitric oxide synthase activity mediates the antinociceptive effect of Crotalus durissus terrificus snake venom, a delta- and kappa-opioid receptor agonist. Life Science, v.75, p.559-573, 2004. Available from: <http://www. ncbi.nlm.nih.gov/pubmed/15158366>. Accessed: Mar. 04, 2014.

ROGER, T. et al. Comparative effects of mu and kappa opiate agonists on the cecocolic motility in the pony. Canadian Journal of
Veterinary Research, v.8, p.163-166, 1994. Available from: <http:// www.ncbi.nlm.nih.gov/pubmed/7954116>. Accessed: Feb. 27, 2014.

SCHULTZ, J.E.J.; GROSS, G.J. Opioids and cardioprotection. Pharmacology and Therapeutics, v.89, p.123-137, 2001. Available from: <http://www.ncbi.nlm.nih. gov/pubmed/11316516>. Accessed: Mar. 05, 2014.

SMITH, M.B.; CHANG, E.B. Antidiarrheals and cathartics. In: WOLFE, M.M. Gastrointestinal pharmacotherapy. Philadelphia: Saunders, 1993. p.139-156.

SOUSA E SILVA, M.C.C. et al. The venom of South American ratllesnake inhibits macrophage functions and is endowed with anti-inflammatory properties. Mediators of Inflammation, v.5, p.18-23, 996. Available from: <http://www.ncbi.nlm.nih.gov/pmc/ articles/PMC2365764/> . Accessed: Feb. 27, 2014. doi: 10.1155/ S0962935196000038.

STUBHAUG, A. et al. Mapping of hyperalgesia around a surgical incision demonstrates that ketamine is powerful suppressor of central sensitization to pain following surgery. Acta Anaesthesiololgica Scandinavica, v.41, p.1124-1132, 1997.

TRUONG, W. et al. Mu opioid receptors and analgesia at a site of a peripheral nerve injury. Annals of Neurology, v.53, p.366375, 2003. Available from: $<$ http://www.ncbi.nlm.nih.gov/ pubmed/12601704>. Accessed: Feb. 07, 2014.

VALADÃO, C.A.A. et al. Administração epidural de opióides em cães. Ciência Rural, v.21, n.2, p.347-355, 2002. Available from: $<$ http://www.scielo.br/scielo.php?script=sci_arttext\&pid=S0103$84782002000200028 \& \operatorname{lng}=\mathrm{pt \& nrm}=\mathrm{iso}>$. Accessed: Mar. 29, 2015. doi: 10.1590/S0103-84782002000200028.

VAN LOON, J.P. et al. Upregulation of articular synovial membrane $\mu$-opioid-like receptors in an acute equine synovitis model. Veterinary Journal, v.196, p.40-46, 2013. Available from: $<$ http://www.ncbi.nlm.nih.gov/pmc/articles/PMC3807052/>. Accessed: Ago. 21, 2015. 